\title{
Sifat Kimia dan Organoleptik Abon Rebung (Dendrocalamus asper Sp.) dengan Penambahan Daging Ayam
}

\author{
Chemical Properties and Organoleptic of Shredded Bamboo Shoots \\ (Dendrocalamus asper Sp.) with Chicken Meat Addition \\ Shenly Dhea Prescilya, Farida Aryani ${ }^{\star}$, Rudito, Mujibu Rahman, \\ Khusnul Khotimah, Netty Maria Naibaho \\ Program Studi Teknologi Hasil Perkebunan, Politeknik Pertanian Negeri Samarinda, Indonesia. \\ *Corresponding Author: ary_ani02@yahoo.com
}

\begin{abstract}
Abstrak
Rebung (Dendrocalamus asper Sp.) digolongkan dalam jenis sayuran karena memiliki banyak kandungan yang bermanfaat bagi kesehatan. Rebung biasa digunakan sebagai bahan masakan sayuran. Peningkatan konsumsi masyarakat terhadap rebung dapat dilakukan dengan diversifikasi rebung menjadi makanan kaya serat yaitu abon rebung. Adapun tujuan penelitian ini adalah untuk mengetahui pengaruh perbandingan ukuran bahan serta perbedaan komposisi antara rebung dan daging ayam terhadap kadar air, kadar abu kadar protein dan kadar serat serta organoleptik warna, aroma, rasa dan tekstur dari abon yang dihasilkan. Metode yang digunakan dalam penelitian ini adalah perhitungan rancangan acak lengkap dan jika perlakuan signifikan maka akan dilanjutkan dengan uji BNJ (Beda Nyata Jujur). Pada penelitian ini menggunakan 2 faktor perlakuan perbandingan ukuran rebung yaitu diblender dan dicincang serta perbedaan komposisi antara rebung dan daging ayam dengan 4 perlakuan dan 3 kali pengulangan, maka unit percobaan pada penelitian ini berjumlah 12 unit percobaan. Parameter yang diamati adalah kadar air, kadar abu, kadar protein, kadar serat dan organoleptik. Berdasarkan analisis sidik ragam, hasil penelitian menunjukkan bahwa perlakuan perbedaan ukuran bahan dan perlakuan variasi daging ayam memberikan pengaruh berbeda nyata terhadap kadar air, kadar abu, kadar protein, kadar serat, uji organoleptik rasa dan tektur abon rebung, namun tidak memberikan pengaruh yang berbeda nyata terhadap warna dan aroma abon yang dihasilkan.
\end{abstract}

Kata kunci: Rebung, Abon, Daging Ayam, Dendrocalamus asper

\begin{abstract}
Bamboo shoots (Dendrocalamus asper Sp.) are classified as vegetables because they contain many health benefits. Bamboo shoots are commonly used as an ingredient in vegetable dishes. Increasing public consumption of bamboo shoots can be done by diversifying bamboo shoots into fiber-rich foods, namely shredded bamboo shoots. The purpose of this study was to determine the effect of bamboo shoots size and the difference in composition between bamboo shoots and chicken meat on water content, ash content, protein content, fiber content, and organoleptic (color, aroma, taste, and texture) on the shredded bamboo that will be produced. The method used in this study is a completely randomized design calculation and if the treatment is significant, it will be continued with Tukey's Honestly Significant. Difference Test. In this study, 2 treatment factors were used to compare the size of bamboo shoots, namely blended and chopped, and the difference in composition between bamboo shoots and chicken with 4 treatments and 3 repetitions. The experimental units in this study amounted to 12 experimental units. Parameters observed were moisture content, ash content, protein content, fiber content, and organoleptic. The results showed that the treatment of differences in material size and treatment of variations in chicken meat gave significantly different effects based on analysis of variance on moisture content, ash content, protein content, and fiber content of shredded bamboo shoots (Dendrocalamus asper Sp). Based on analysis of variance, the results showed that the treatment of differences in material size and treatment of variations in chicken meat had a significantly different effect on water content, ash content, protein content, fiber content, organoleptic test of taste and texture of bamboo shoot shreds, but did not give a significantly different effect on the color and aroma of the resulting shredded
\end{abstract}

Keywords: Bamboo shoots, Shredded, Chicken, Dendrocalamus asper. 


\section{PENDAHULUAN}

Rebung digolongkan dalam jenis sayuran karena memiliki banyak kandungan yang bermanfaat bagi kesehatan. Meskipun sudah banyak digunakan sebagai bahan utama masakan, tapi belum banyak yang memanfaatkan rebung sebagai camilan bercita rasa lezat. Rebung adalah tunas muda dari akar pohon bambu yang berpotensi diolah menjadi aneka macam olahan pangan, salah satunya abon karena mengandung kadar serat (Haryani,dkk. 2014)

Abon termasuk makanan ringan atau lauk yang siap saji. Produk tersebut sudah dikenal oleh masyarakat umum sejak dulu. Abon dibuat dari daging yang diolah sedemikian rupa sehingga memiliki karakteristik kering, ringan, renyah, dan gurih. Pada umumnya, daging yang digunakan dalam pembuatan abon yaitu daging sapi atau kerbau. Sebenarnya, semua jenis daging seperti daging ayam bahkan ikan dapat digunakan sebagai bahan baku abon.

Tidak hanya itu, untuk memenuhi keinginan konsumen, kini abon dibuat dengan rasa yang bervariasi. Beberapa rasa abon yang ada di pasar yaitu manis, asin, dan pedas (Nur'aini. dkk., 2019). Oleh karena itu, perbaikan mutu nutrisi dari segi serat kasar abon maka perlu dilakukan penelitian terhadap rebung dan diolah menjadi abon rebung.

\section{METODE PENELITIAN}

\section{A. Waktu dan Tempat Penelitian}

Penelitian ini dilakukan pada bulan Mei sampai dengan bulan Agustus 2021 berlokasi di Laboratorium Pengolahan Hasil Perkebunan dan Laboratorium Kimia Analitik, Program Studi Teknologi Hasil Perkebunan, Politeknik Pertanian Negeri Samarinda.

\section{B. Alat dan Bahan}

Alat yang digunakan adalah alat tulis, wajan, sutil kayu dan besi, press abon, timbangan analitik dan digital, pisau, talenan, baskom, tirisan, spatula, blender, sendok, plastik, toples, panci pengukus, kompor dan gas, erlenmeyer, gelas ukur, kuvet, mikropipet, pipette tips, labu takar, centrifuge, cawan krus, spektrofotometer, oven, tabung reaksi, vortex, dan tanur pengabuan.

Bahan yang digunakan dalam penelitian ini adalah adalah rebung, daging ayam, bawang putih, bawang merah, kemiri, ketumbar, lengkuas, gula, garam, lada, serai, minyak goreng, sedangkan bahan kimia yang digunakan adalah Bovine Serum Albumine (BSA), $\mathrm{NaOH}, \mathrm{CuSO}_{4}, \mathrm{Na}_{2} \mathrm{CO}_{3}, \mathrm{NaKTrartat}$, Folin, $\mathrm{H}_{2} \mathrm{SO}_{4}$, aquades, dan alkohol.

\section{Rancangan Penelitian}

Penelitian ini menggunakan Rancangan Acak Lengkap (RAL) dengan dua faktor dan tiga ulangan. Faktor pertama adalah jenis ukuran rebung $(A)$ yang terdiri dari dua taraf yaitu $\mathrm{A} 1$ = blender, $\mathrm{B} 2$ = cincang. sedangkan faktor kedua adalah Variasi daging ayam (B) yang terdiri dari dua taraf, yaitu : $\mathrm{B} 1=80 \%$ rebung : $20 \%$ daging ayam, B2 $=60 \%$ rebung : $40 \%$ daging ayam, sehingga diperoleh perlakuan $\mathrm{P} 1$ hingga $\mathrm{P} 4$.

$\mathrm{P} 1=\mathrm{A} 1 \mathrm{~B} 1$ 80\% (560 gram) rebung blender : $20 \%$ (140 gram) daging ayam.

$\mathrm{P} 2=\mathrm{A} 1 \mathrm{~B} 2$ 60\% (420 gram) rebung blender : $40 \%$ (280 gram) daging ayam

$\mathrm{P} 3=\mathrm{A} 2 \mathrm{~B} 1 \mathrm{80} \%$ (560 gram ) rebung cincang : $20 \%$ (140 gram) daging ayam

$\mathrm{P} 4=\mathrm{A} 2 \mathrm{~B} 2$ 60\% (420 gram) rebung cincang : $40 \%$ (280 gram) daging ayam

Setiap jenis perlakuan dilakukan dengan tiga kali ulangan. Selanjutnya analisis data dilakukan dengan analisis ragam. Jika pada sidik ragam terdapat perbedaan yang nyata pada perlakuan, maka akan dilanjutkan dengan uji lanjut Beda Nyata Jujur pada taraf a $5 \%$.

\section{Proses Pembuatan Abon Rebung}

Alat dan bahan disiapkan kemudian ditimbang semua bahan dengan menggunakan timbangan digital. Bahanbahan seperti bawang merah, bawang putih, kemiri, lengkuas, serai diblender dengan kecepatan rendah selama 3 menit. Kemudian bumbu yang sudah diblender dimasak dengan menggunakan api sedang sampai kekuningan lalu ditambahkan lada, ketumbar, gula, garam dan minyak goreng secukupnya. Setelah bumbu masak, dimasukkan rebung yang sudah diblender atau dicincang dan daging ayam yang sudah disuwir. Kemudian rebung dan daging ayam disangrai hingga mengering atau bewarna kecoklatan. Setelah abon mengering kemudian dipress 
menggunakan alat press hingga minyak keluar semua.

\section{E. Parameter Pengujian}

Parameter yang diuji pada abon rebung adalah kadar air (Santoso dkk, 2020), kadar abu (Santoso dkk, 2020), kadar protein (Hasan, 2010), kadar serat (AOAC, 2005), dan uji organoleptik (tekstur, aroma, rasa dan warna) (Ayustaningwarno, 2014 ).

\section{Uji Kadar Air Metode Oven (Santoso dkk, 2020)}

Cawan dikeringkan dalam oven terlebih dahulu selama 15 menit. Kemudian didinginkan dalam desikator selama 15 menit lalu berat cawan ditimbang dan dicatat. Kemudian ditimbang sampel sebanyak 2 gram. Setelah itu, sampel dalam cawan dikeringkan didalam oven dengan suhu $105^{\circ} \mathrm{C}$ selama 3 jam. Lalu didinginkan dalam desikator selama 15 menit. Kemudian cawan dan bahan didalamnya ditimbang dan catat hasilnya. Setelah itu dikeringkan dalam oven kembali hingga diperoleh berat konstan atau tetap. Perhitungan kadar air dengan rumus sebagai berikut

$$
\text { Kadar air }(\%)=\frac{(W 1+W 2)-W 3}{W 2} \times 100 \%
$$

Keterangan:

W1 = Berat cawan kosong (gram)

W2 $=$ Berat sampel (gram)

W3 = Berat cawan dan sampel setelah oven (gram)

\section{Uji Kadar Abu Metode Pengabuan Kering (Santoso dkk, 2020)}

Sebanyak 2-3 gram sampel dimasukkan ke dalam sebuah cawan porselen (atau platina) yang telah diketahui bobotnya, untuk sampel cairan uapkan di atas penangas air sampai kering. Sampel diarangkan di atas nyala pembakar, lalu diabukan dalam tanur listrik pada suhu $550^{\circ} \mathrm{C}-600^{\circ} \mathrm{C}$ sampai pengabuan sempurna (sesekali pintu tanur dibuka sedikit agar oksigen bisa masuk). Dinginkan dalam desikator, lalu timbang hingga bobot tetap.

$$
\text { Kadar abu }=\frac{W 1-W 2}{W} \times 100 \%
$$

\author{
Keterangan: \\ W = Bobot cuplikan (gram) \\ W1 = Bobot contoh + cawan sesudah \\ diabukan (gram) \\ W2 = Bobot cawan kosong (gram)
}

\section{Uji Kadar Protein Metode Lowry} (Hasan, 2010)

a. Pembuatan Kurva Standar

Masukkan ke dalam tabung reaksi 0 (blanko), 0,1; 0,2; 0,4; 0,6; 0,8 dan $1 \mathrm{ml} \mathrm{BSA}$ sehingga diperoleh konsentrasi masingmasing $6,25 \mu \mathrm{g} / \mathrm{mL}, 12,5 \mu \mathrm{g} / \mathrm{mL}, 25 \mu \mathrm{g} / \mathrm{mL}$, $37,5 \mu \mathrm{g} / \mathrm{mL}, 50 \mu \mathrm{g} / \mathrm{mL}$ dan $62,5 \mu \mathrm{g} / \mathrm{mL}$. Kemudian ditambahkan air hingga volume total masing-masing $4 \mathrm{ml}$. Kemudian ditambahkan $5,5 \mathrm{~mL}$ reagen lowry $\mathrm{B}$ ke dalam tabung reaksi masing-masing, kemudian dihomogenkan dan didiamkan selama 15 menit pada suhu kamar. Selanjutnya ditambahkan $0,5 \mathrm{ml}$ pereaksi reagen folin ke dalam masing-masing tabung reaksi. Dihomogenkan dengan cepat setelah penambahan. Diamkan selama \pm 30 menit hingga terbentuk warna biru. Larutan kemudian dimasukkan ke dalam kuvet dan dilakukan pembacaan pada Spektrofotometer UV-Vis dengan panjang gelombang $650 \mathrm{~nm}$. Dibuat kurva standar.

b. Persiapan Sampel

Sebanyak 2 gram sampel ditimbang, kemudian dihaluskan dengan menambahkan $100 \mathrm{ml}$ aquades dan disaring ekstraknya. Protein yang mengendap dipisahkan dengan sentrifuge $11.000 \mathrm{rpm}$ selama 10 menit. Dipisahkan supernatannya. Presipitat yang merupakan protein kemudian perlu dilarutkan kembali dengan buffer asam asetat $\mathrm{pH}$ 5,0 hingga mencapai volume $10 \mathrm{ml}$. Kemudian diambil $1 \mathrm{ml}$ dari protein sampel dan dilakukan prosedur seperti pada perlakuan penyiapan kurva standar mulai dari penambahan reagen lowry dan seterusnya. Kemudian ditentukan kadar protein dari absorban yang didapat dari larutan sampel dengan menggunakan kurva standar BSA.

Kadar Protein (\%)

$$
=\frac{\text { Berat Protein hasil kurva }(\mathrm{mg})}{\text { Berat Sampel }(\mathrm{mg})} \times 100 \%
$$




\section{Uji Kadar Serat Kasar (AOAC, 2005)}

Ditimbang 1-2 gram sampel (dibebaskan lemaknya dengan cara ekstrasi soxhletasi atau dengan cara mengaduk, mengendap tuangkan sampel dalam pelarut organik sebanyak 3 kali kemudian dikeringkan contoh dan dimasukan ke dalam Erlenmeyer 500 $\mathrm{mL}$ ) ditambahkan $50 \mathrm{~mL}$ larutan $\mathrm{H}_{2} \mathrm{SO}_{4}$ $1,25 \%$ kemudian dididihkan selama 30 menit dengan menggunakan pendingin tegak. Sebanyak 50 mL NaOH 3,25\% ditambahkan kemudian dididihkan lagi selama 30 menit. Dalam keadaan panas disaring dengan corong Bucher yang berisi kertas saring tak berbau Whatman 541 yang telah dikeringkan dan diketahui bobotnya (W1). Endapan yang terdapat pada kertas saring dicuci berturutturut dengan $\mathrm{H}_{2} \mathrm{SO}_{4} 1,25 \%$ panas, aquades panas, dan etanol 96\%. Kertas saring diangkat dan dimasukan pada kotak timbang yang telah diketahui bobotnya (W2) kemudian dikeringkan pada suhu $105^{\circ} \mathrm{C}$ didinginkan dan ditimbang sampai bobot tetap (W3).

$$
\% \text { serat } \text { kasar }=\frac{(\mathrm{W} 3-\mathrm{W} 2)-\mathrm{W} 1}{\text { berat sampel }} \times 100 \%
$$

\section{Uji Organoleptik}

Unsur-unsur mutu atau kualitas sensoris pada abon adalah aroma, warna, tekstur dan rasa (Utami dkk., 2016). Pengamatan dilakukan berdasarkan tingkat kesukaan panelis. Dalam pengujian organoleptik dikenal beberapa macam panel. Penggunaan panel-panel ini berbeda tergantung dari tujuan pengujian tersebut. Untuk pengujian organoleptik pada penelitian ini memakai panel tidak terlatih karena hanya perlu sekelompok orang yang mempunyai kemampuan untuk membedakan reaksi dari penilaian organoleptik yang diujikan. Jumlah anggota panel tidak terlatih berkisar antara 25-100 orang (Ayustaningwarno, 2014).

Tingkat kesukaan pada uji hedonik disebut skala hedonik. Skala hedonik ada yang memiliki skala numerik 1-5, 1-7 hingga 1-9. Menurut Satiarini (2006), skala hedonik dari 1 sampai 5 meliputi:

1 : Sangat tidak suka

2 : Tidak suka

3 : Agak suka

4 : Suka

5 : Sangat suka

\section{HASIL DAN PEMBAHASAN}

Hasil penelitian dan analisis yang dilakukan, secara umum menunjukkan bahwa perbedaan ukuran bahan dan perlakuan variasi daging ayam memberikan pengaruh berbeda nyata bedasarkan analisis sidik ragam terhadap kadar air, kadar abu, kadar protein dan kadar serat abon rebung.

\section{A. Karakteristik Kimia Kadar Air}

Tujuan pada uji kadar air adalah untuk mengetahui jumlah air yang terdapat dalam produk akhir yang dihasilkan. Kadar air suatu bahan berhubungan dengan daya simpan bahan, hal ini disebabkan karena air yang terkandung didalamnya dapat mengakibatkan media tumbuh mikroba yang menyebabkan kerusakan. (Winarno, 1997). Semakin banyak kadar air yang terkandung dalam suatu bahan maka akan mengakibatkan penurunan kualitas terhadap produk yang akan dihasilkan. Hasil penelitian terhadap rata-rata uji kadar air abon rebung (Dendrocalamus asper) dapat dilihat pada Gambar 1.

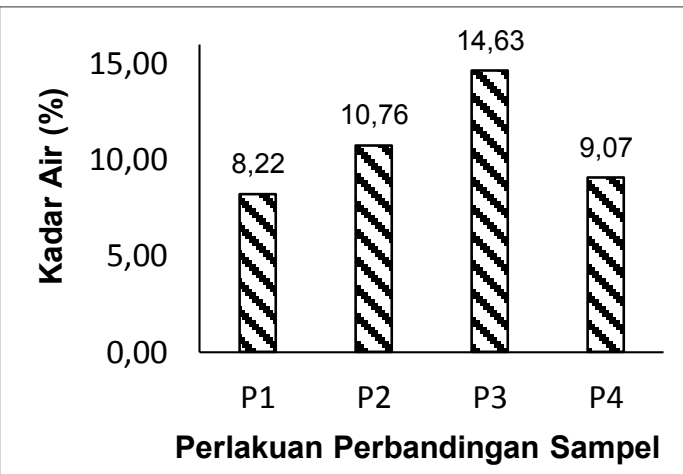

Gambar 1. Rerata Hasil Uji Kadar Air Abon Rebung dengan Perbandingan Sampel

Gambar 1. menunjukkan nilai rata-rata kadar air dari abon rebung dengan pengolahan rebung yang berbeda yaitu diblender dan dicincang serta konsentrasi daging ayam yang berbeda diperoleh kadar air yang tertinggi pada P3 $80 \%$ rebung dicincang. Tingginya kadar air pada $\mathrm{P} 3$ diduga ada beberapa faktor penyebab yaitu ukuran partikel yang lebih besar sehingga pada proses penyangraian tidak merata sehingga pengeringan pada abon kurang sempurna maka air yang terkandung dalam bahan tidak dapat seluruhnya diuapkan dan 
tingginya kadar air pada perlakuan ini mengakibatkan abon lebih cepat rusak atau berjamur. Sedangkan kadar air terendah yaitu pada $\mathrm{P} 180 \%$ rebung diblender hal ini dikarenakan tekstur atau ukuran rebung yang diblender lebih kecil dibandingkan rebung yang dicincang, sehingga proses penyangraian lebih merata dan pengeringan lebih sempurna

Pada semua perlakuan pada uji kadar air abon rebung, $\mathrm{P} 1$ sampai $\mathrm{P} 4$ tidak sesuai dengan SNI 01-3707-1995 dimana kadar air pada abon maksimal $7 \%$. Kadar air abon yang tinggi ini diduga disebabkan oleh proses penyangraian yang kurang sempurna sehingga menyebabkan abon yang dihasilkan masih memiliki kandungan air diatas standar. Kadar air sangat berpengaruh terhadap mutu bahan pangan sehingga dalam proses pengolahan dan penyimpanan bahan pangan, air perlu dikeluarkan, salah satunya dengan cara pengeringan (Argo, 2018)

Data tersebut kemudian dianalisis menggunakan sidik ragam untuk mengetahui apakah perlakuan pengolahan rebung dan penambahan daging ayam berpengaruh signifikan atau tidak signifikan terhadap kandungan kadar air pada abon rebung dengan pengolahan bahan dan konsentrasi yang berbeda.

Hasil analisis sidik ragam memperlihatkan bahwa perlakuan $\mathrm{B}, \mathrm{F}$ hitung lebih kecil dari $F$ tabel yang berarti tidak berbeda nyata, perlakuan A $\mathrm{F}$ hitung lebih besar dari dari $\mathrm{F}$ tabel $5 \%$ yaitu berbeda nyata, dan Interaksi antara perlakuan $A$ dan Perlakuan B F hitung lebih besar dari $\mathrm{F}$ tabel $5 \%$ dan $\mathrm{F}$ tabel $1 \%$ yaitu sangat berbeda nyata maka akan dilanjutkan dengan Uji BNJ. Setelah dilakukan uji lanjut dengan BNJ, P1,P4,P2 tidak berbeda nyata, sedangkan P3 berbeda nyata dengan perlakuan P1,P4,P3.

\section{Kadar Abu}

Kadar abu merupakan residu anorganik dari proses pembakaran atau oksidasi komponen organik bahan pangan. Kadar abu dari bahan menunjukkan kandungan mineral yang terdapat dalam bahan tersebut, kemurnian, serta kebersihan suatu bahan yang dihasilkan. Analisis kadar abu dengan metode pengabuan kering dilakukan dengan mendetruksi komponen organiksampel dengan suhu tinggi $300-500^{\circ} \mathrm{C}$ di dalam tanur pengabuan (Andarwulan dkk, 2011). Hasil penelitian terhadap rata-rata uji kadar abu abon rebung (Dendrocalamus asper) dapat dilihat pada Gambar 2.

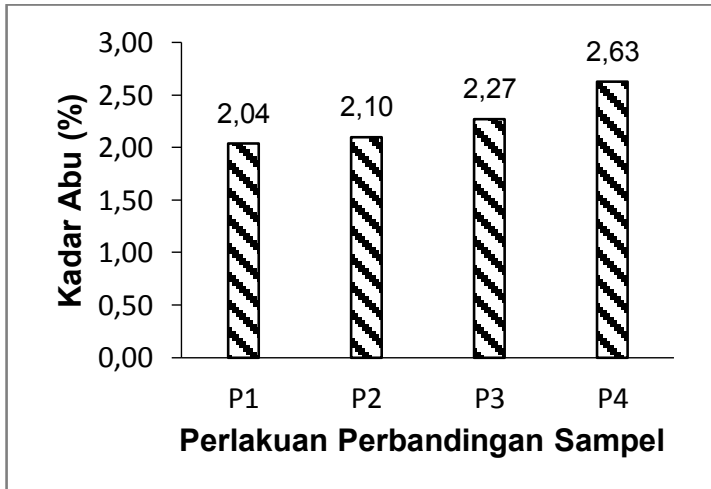

Gambar 2. Rerata Hasil Uji Kadar Abu Abon Rebung dengan Perbandingan Sampel

Hasil kadar abu yang diperoleh menggambarkan banyaknya mineral yang tidak terbakar menjadi zat yang tidak dapat menguap. Kadar abu abon yang dihasilkan adalah yang tertinggi yaitu $2,63 \%$ dan terendah 2,04\% masih memenuhi standar SNI yaitu maksimal 7\%. Rendahnya nilai kadar abu ini diduga karena proses perebusan dan pencucian rebung sampai dengan 3 kali pengulangan sehingga ketersediaan mineral akan larut oleh air yang digunakan pada saat perebusan rebung.

Menurut Andarwulan dkk (2011), pengaruh pengolahan pada bahan dapat mempengaruhi ketersediaan mineral bagi tubuh. Penggunaan air pada proses pencucian, perendaman dan perebusan dapat mengurangi ketersediaan mineral karena mineral akan larut oleh air yang digunakan.

Data tersebut kemudian dianalisis menggunakan sidik ragam untuk mengetahui apakah perlakuan pengolahan rebung dan penambahan daging ayam berpengaruh signifikan atau tidak signifikan terhadap kandungan kadar abu pada abon rebung dengan pengolahan bahan dan konsentrasi yang berbeda.

Hasil analisis sidik ragam memperlihatkan bahwa perlakuan B $\mathrm{F}$ hitung lebih besar dari $\mathrm{F}$ tabel $5 \%$ dan $\mathrm{F}$ tabel $1 \%$ yang berarti berbeda sangat nyata, perlakuan A $F$ hitung lebih besar dari dari $F$ tabel $5 \%$ dan $F$ tabel $1 \%$ yaitu berbeda sangat nyata, dan Interaksi antara perlakuan A dan 
Perlakuan B F hitung lebih besar dari $\mathrm{F}$ tabel $5 \%$ yaitu berbeda nyata maka akan dilanjutkan dengan Uji BNJ. Setelah dilakukan uji lanjut dengan BNJ, P1,P2,P3 tidak berbeda nyata, sedangkan $\mathrm{P} 4$ berbeda nyata dengan perlakuan $\mathrm{P} 1, \mathrm{P} 2, \mathrm{P} 3$.

\section{Kadar Protein}

Analisis protein dapat dilakukan dengan dua cara yaitu secara langsung menggunakan zat kimia yang spesifik terhadap protein seperti metode lowry dan secara tidak langsung dengan menghitung jumlah nitrogen yang terkandung di dalam bahan seperti metode kjeldahl (Sudarmadji dkk., 2007). Dalam penelitian ini dilakukan uji kadar protein menggunakan metode lowry. Hasil penelitian terhadap rata-rata kadar protein abon. Adapun penyajian data dalam protein abon dapat dilihat pada Gambar 3.

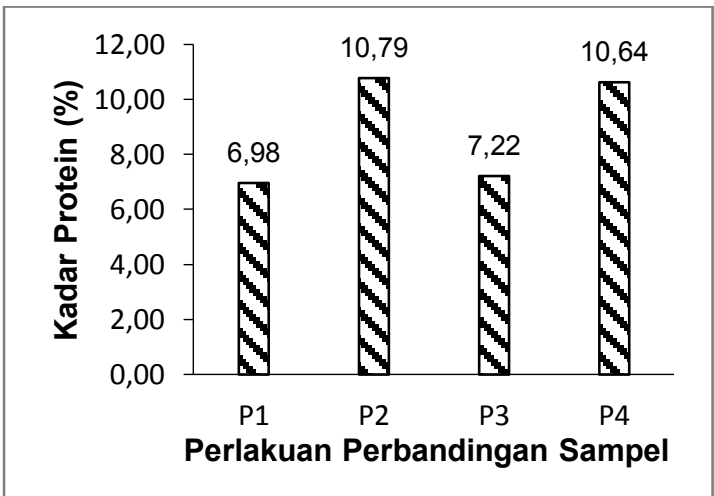

Gambar 3. Rerata Hasil Uji Kadar Protein Abon Rebung dengan Perbandingan Sampel

Penambahan daging ayam berpengaruh terhadap kadar protein abon. Hal ini dikarenakan kandungan protein pada daging ayam yang cukup tinggi dibandingkan dengan kandungan protein rebung. Semakin banyak konsentrasi daging ayam yang ditambahkan maka semakin tinggi kandungan protein yang dihasilkan. Kadar protein dari abon rebung yang diperoleh dari semua perlakuan yaitu P1 sampai P4 adalah sebesar 6,98\%-10,79\%, maka tidak mencapai standar mutu abon yaitu $20 \%$. Rendahnya kadar protein abon erat hubungannya dengan kadar protein bahan baku abon yang digunakan (Chairita, 2008).

Data tersebut kemudian dianalisis menggunakan sidik ragam untuk mengetahui apakah perlakuan penambahan berpengaruh signifikan atau tidak signifikan terhadap kandungan kadar protein pada abon rebung dengan pengolahan bahan dan konsentrasi yang berbeda.

Hasil analisis sidik ragam memperlihatkan bahwa perlakuan B $\mathrm{F}$ hitung lebih besar dari $\mathrm{F}$ tabel $5 \%$ dan $\mathrm{F}$ tabel $1 \%$ yang berarti berbeda sangat nyata, perlakuan A $\mathrm{F}$ hitung lebih kecil dari dari $\mathrm{F}$ tabel $5 \%$ yaitu tidak berbeda nyata, dan Interaksi antara perlakuan A dan Perlakuan B F hitung lebih kecil dari $\mathrm{F}$ tabel $5 \%$ yaitu tidak berbeda nyata maka akan dilanjutkan dengan Uji BNJ. Setelah dilakukan uji lanjut dengan BNJ, P1 Dan P3 tidak berbeda nyata, sedangkan P2 dan P4 berbeda nyata dengan perlakuan P1 dan P3.

\section{Kadar Serat Kasar}

Penelitian dilakukan untuk mengetahui kadar serat yang terkandung dalam abon dengan campuran rebung dan daging ayam dengan komposisi pengolahan rebung dan konsentrasi daging ayam yang berbeda. Adapun rata-rata kadar serat abon rebung dapat dilihat pada Gambar 4.

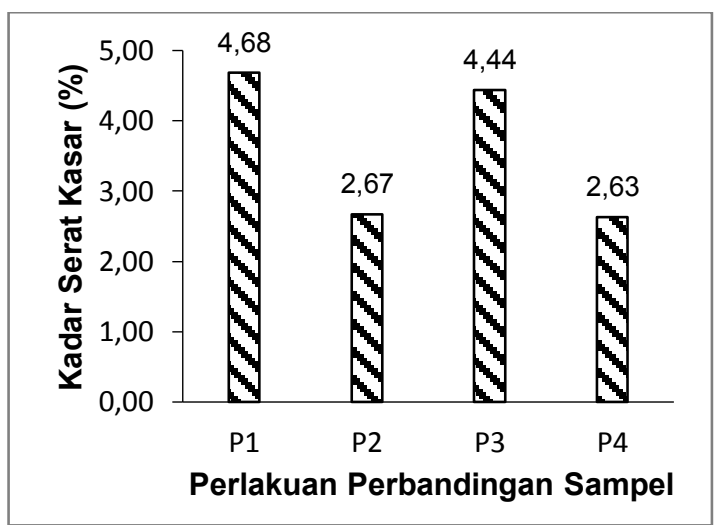

Gambar 4. Rerata Hasil Uji Kadar Serat Kasar Abon Rebung dengan Perbandingan Sampel

Pada pengujian kadar serat abon menunjukkan bahwa P1 dan P3 memberikan kadar serat kasar lebih tinggi dibanding P2 dan P4. Semakin banyak penambahan rebung maka semakin tinggi kadar serat kasar yang terkandung dalam abon. Hasil analisis sidik ragam memperlihatkan bahwa perlakuan $\mathrm{B} F$ hitung lebih besar dari $\mathrm{F}$ tabel $5 \%$ dan $\mathrm{F}$ tabel $1 \%$ yang berarti berbeda sangat nyata, perlakuan A F hitung lebih kecil dari dari $F$ tabel $5 \%$ yaitu tidak berbeda nyata, dan Interaksi antara perlakuan $\mathrm{A}$ dan Perlakuan $B \mathrm{~F}$ hitung lebih kecil dari $\mathrm{F}$ tabel 
$5 \%$ yaitu tidak berbeda nyata maka akan dilanjutkan dengan Uji BNJ. Setelah dilakukan uji lanjut dengan BNJ, P1 Dan P3 tidak berbeda nyata, sedangkan $\mathrm{P} 2$ dan $\mathrm{P} 4$ berbeda nyata dengan perlakuan $\mathrm{P} 1$ dan $\mathrm{P} 3$.

\section{B. Karakteristik Organoleptik Warna}

Faktor warna sangat menentukan penilaian bahan pangan sebelum faktorfaktor lain dipertimbangkan, dikarenakan warna berperan penting dalam proses penerimaan konsumen terhadap suatu produk pangan. Hal yang pertama dilihat oleh seseorang apabila hendak memilih suatu pangan tertentu, yaitu dengan mengamati tampilan warna. Selain itu, warna juga dapat menjadi pemberi informasi terhadap perubahan kimia yang terjadi pada sebuah makanan. Adapun hasil organoleptik terhadap warna dapat dilihat pada Gambar 5.

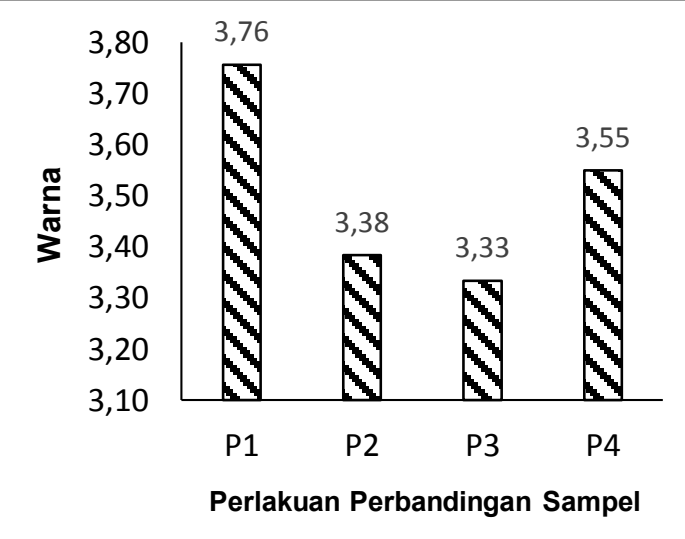

Gambar 5. Rerata Hasil Organoleptik Warna Abon Rebung dengan Perbandingan Sampel

Berdasarkan Gambar 6 menunjukkan bahwa hasil dari pengujian organoleptik warna pada abon rebung yaitu memiliki nilai rata-rata berkisar antara 3,33 sampai dengan 3,76 . Hal ini berarti warna dari abon rebung ini masuk pada range agak suka - suka.

Warna abon semakin coklat dengan bertambahnya persentase penambahan rebung dan daging ayam yang berbeda, serta waktu penyangraian yang cukup lama hal ini dipengaruhi oleh adanya reaksi Maillard.

Menurut Rosiani dkk., (2015), reaksi Maillard terkait dengan aroma, rasa dan warna terutama dalam makanan seperti proses pemanggangan biji kopi, roti, sereal dan pemasakan daging. Reaksi Maillard terjadi karena adanya gugus amino bebas dari protein berikatan dengan gugus hidriksol dari gula reduksi yang menyebabkan terbentuknya senyawa melanoidin yang berwarna coklat. Terjadinya reaksi Maillard dalam penelitian ini yaitu ketika abon mengalami proses perebusan serta penyangraian secara deep frying.

Data tersebut kemudian dianalisis menggunakan sidik ragam untuk mengetahui apakah perlakuan penambahan berpengaruh signifikan atau tidak signifikan terhadap warna pada abon rebung dengan pengolahan bahan dan konsentrasi yang berbeda. Hasil analisis sidik ragam memperlihatkan bahwa perlakuan $\mathrm{B} F$ hitung lebih kecil dari $\mathrm{F}$ tabel $5 \%$ dan $\mathrm{F}$ tabel $1 \%$ yang berarti tidak berbeda nyata, perlakuan A F hitung lebih kecil dari dari $F$ tabel $5 \%$ yaitu tidak berbeda nyata, dan Interaksi antara perlakuan A dan Perlakuan B $\mathrm{F}$ hitung lebih kecil dari $\mathrm{F}$ tabel $5 \%$ yaitu tidak berbeda nyata.

\section{Aroma}

Aroma merupakan bau dari produk makanan, suatu respon ketika senyawa volatil dari suatu makanan masuk ke rongga hidung dan dirasakan oleh sistem olfaktori adalah bau. Senyawa volatil masuk ke dalam hidung ketika manusia bernafas atau menghirupnya, namun juga dapat masuk dari belakang tenggorokan selama seseorang makan. Senyawa aroma bersifat volatil, sehingga mudah mencapai sistem penciuman di bagian atas hidung, dan perlu konsentrasi yang cukup untuk dapat berinteraksi dengan satu atau lebih reseptor penciuman. Senyawa aroma memainkan peran penting dalam produksi penyedap, yang digunakan di industri jasa makanan, untuk meningkatkan rasa dan umumnya meningkatkan daya tarik produk makanan tersebut (Tarwendah, 2017).

Aroma adalah rasa dan bau yang sangat subjektif serta sulit diukur, karena setiap orang mempunyai sensitifitas dan kesukaan yang berbeda. Aroma yang timbul pada abon rebung ini didominasi oleh aroma rempahrempah serta daging ayam. Hal ini dikarenakan rempah-rempah berfungsi sebagai pemberi aroma dan rasa pada abon rebung.

Aroma pada pembuatan abon rebung dengan konsentrasi daging ayam yang berbeda yang disajikan pada gambar 6 terlihat bahwa dengan penambahan daging 
ayam, abon tersebut cenderung masih terasa beraroma daging ayam sehingga data yang dihasilkan juga agak suka dengan abon tersebut. Ciri khas aroma pada daging ayam membuat beberapa panelis suka dengan abon tersebut.

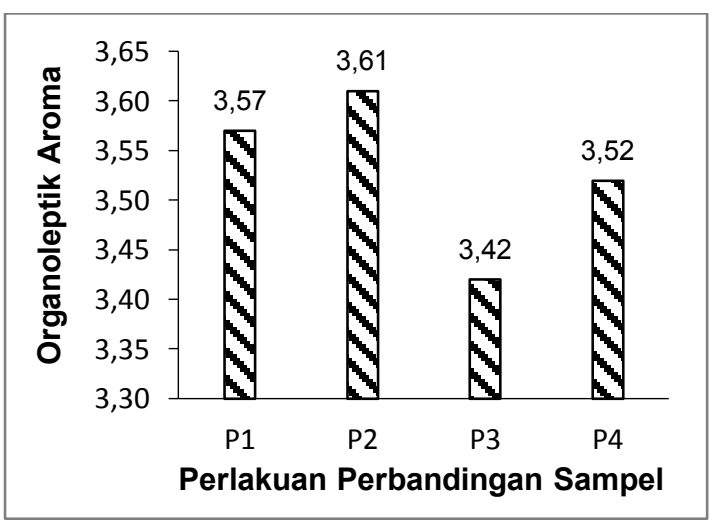

Gambar 6. Rerata Hasil Organoleptik Aroma Abon Rebung dengan Perbandingan Sampel

Data tersebut kemudian dianalisis menggunakan sidik ragam untuk mengetahui apakah perlakuan penambahan berpengaruh signifikan atau tidak signifikan terhadap aroma pada abon rebung dengan pengolahan bahan dan konsentrasi yang berbeda. Hasil analisis sidik ragam memperlihatkan bahwa perlakuan B F hitung lebih kecil dari $\mathrm{F}$ tabel $5 \%$ dan $\mathrm{F}$ tabel $1 \%$ yang berarti tidak berbeda nyata, perlakuan $\mathrm{A}$ $F$ hitung lebih kecil dari dari $F$ tabel $5 \%$ yaitu tidak berbeda nyata, dan Interaksi antara perlakuan A dan Perlakuan B F hitung lebih kecil dari $F$ tabel $5 \%$ yaitu tidak berbeda nyata.

\section{Rasa}

Faktor penentu daya terima konsumen terhadap produk makanan yang dihasilkan adalah rasa, dan juga merupakan bagian penting dari suatu produk makanan. Penilaian organoleptik akan rasa pada makanan lebih banyak menggunakan alat indera perasa manusia. Pengindraan rasa dibagi menjadi 4 faktor yaitu asin, asam, manis,dan pahit (Montolalu et al., 2013). Rasa yang timbul pada abon rebung ini adalah rasa daging ayam dan rempahrempah. Hasil penelitian terhadap rata-rata tingkat kesukaan panelis terhadap rasa pada abon rebung dapat dilihat pada Gambar 7 .

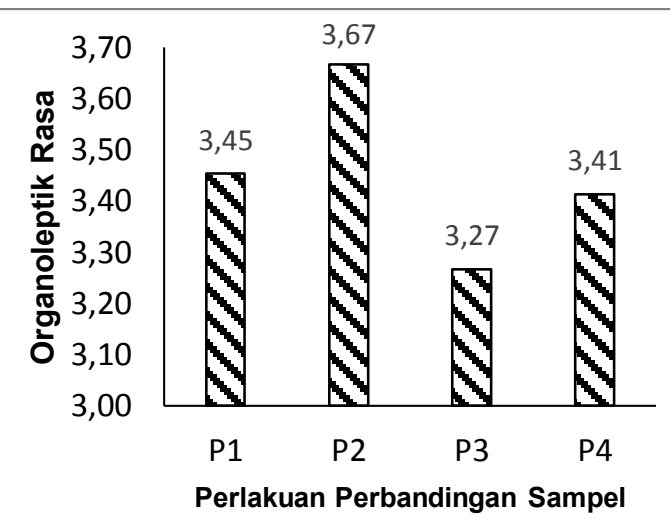

Gambar 7. Rerata Hasil Organoleptik Rasa Abon Rebung dengan Perbandingan Sampel

Gambar 7 menunjukkan bahwa hasil dari pengujian organoleptik rasa pada abon rebung yaitu memiliki nilai rata-rata berkisar antara 3,27 sampai dengan 3,67. Hal ini berarti rasa abon rebung ini masuk pada range skala agak suka hingga suka.

Jumlah rata-rata tertinggi pada rasa ditunjukkan pada perlakuan (P2), yaitu dengan penambahan rebung yang diblender sebanyak 560 gram dan daging ayam sebanyak 140 gram dengan hasil rata-rata sebesar 3,67 pada range skala suka. Sedangkan jumlah rata-rata terendah pada pengujian organoleptik warna ini terdapat pada perlakuan (P3) yaitu dengan penambahan rebung cincang sebanyak 560 gram dan daging ayam sebanyak 140 gram dengan hasil rata-rata sebesar 3,27 pada range skala agak suka.

Data tersebut kemudian dianalisis menggunakan sidik ragam untuk mengetahui apakah perlakuan penambahan berpengaruh signifikan atau tidak signifikan terhadap rasa pada abon rebung dengan pengolahan bahan dan konsentrasi yang berbeda. Hasil analisis sidik ragam memperlihatkan bahwa perlakuan $B$ F hitung lebih besar dari $F$ tabel $5 \%$ yang berarti berbeda nyata, perlakuan $A$ $F$ hitung lebih besar dari dari $F$ tabel $5 \%$ dan $\mathrm{F}$ tabel $1 \%$ yaitu sangat berbeda nyata, dan Interaksi antara perlakuan A dan Perlakuan B $\mathrm{F}$ hitung lebih kecil dari $\mathrm{F}$ tabel $5 \%$ yaitu tidak berbeda nyata maka akan dilanjutkan dengan Uji BNJ.

\section{Tekstur}

Tingkat kesukaan terhadap tekstur pada pembuatan abon rebung dengan pengolahan yang berbeda dan konsentrasi daging ayam yang berbeda diketahui melalui uji 
organoleptik. Pengujian menggunakan 25 orang panelis. Pengujian tekstur pada pembuatan abon sangat penting dilakukan, karena tekstur merupakan hal yang harus disesuaikan dengan jenis suatu produk. Adapun penyajian data rata-rata dalam bentuk grafik, dapat dilihat pada Gambar 8 .

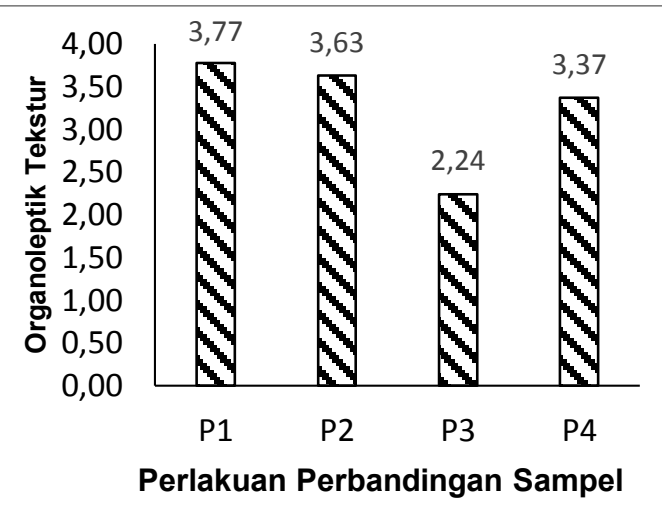

Gambar 8. Rerata Hasil Organoleptik Tekstur Abon Rebung dengan Perbandingan Sampel

Gambar 8 menunjukkan bahwa hasil Tekstur tertinggi terdapat pada P1 yaitu 3,77 hal ini dikarenakan pada perlakuan 1 pengolahan rebung yaitu dengan cara diblender sedangkan perlakuan terendah yaitu P2 2,24 dengan menggunakan rebung yang dicincang. Maka dapat disimpulkan bahwa proses pengolahan rebung yang meliki tekstur halus yaitu diblender memiliki merupakan suatu hal yang berhubungan dengan struktur makanan yang dirasakan di mulut. Tekstur adalah penginderaan yang dihubungan dengan rabaan atau sentuhan. Tekstur juga sering dianggap sama penting dengan bau, rasa dan aroma karena mempengaruhi citarasa makanan. Tekstur meliputi rasa garing dan kekerasan makanan yang dirasakan oleh indera pengecap. Tekstur dapat mempengaruhi rasa yang ditimbulkan oleh makanan.

Data tersebut kemudian dianalisis menggunakan sidik ragam untuk mengetahui apakah perlakuan penambahan berpengaruh signifikan atau tidak signifikan terhadap tekstur pada abon rebung dengan pengolahan bahan dan konsentrasi yang berbeda. Setelah dilakukan uji lanjut dengan BNJ, P1, P2, dan P4 tidak berbeda nyata, sedangkan $\mathrm{P} 2$ berbeda nyata dengan perlakuan $\mathrm{P} 1, \mathrm{P} 2$, dan $\mathrm{P} 4$.

\section{KESIMPULAN DAN SARAN}

\section{A. Kesimpulan}

Berdasarkan hasil dari penelitian studi pembuatan abon dari rebung (Dendrocalamus asper Sp.) dapat disimpulkan sebagai berikut:

1. Hasil penelitian menunjukkan perlakuan perbedaan ukuran bahan dan perlakuan variasi daging ayam memberikan pengaruh berbeda nyata bedasarkan analisis sidik ragam terhadap Kadar air, kadar abu, kadar protein dan kadar serat abon rebung (Dendrocalamus asper Sp).

2. Perlakuan perbedaan ukuran bahan dan perlakuan variasi daging ayam pada pembuatan abon rebung memberikan pengaruh berbeda nyata terhadap rasa dan tekstur. Akan tetapi, memberikan pengaruh tidak berbeda nyata terhadap warna dan aroma.

\section{B. Saran}

Dalam pembuatan abon rebung sebaiknya menggunakan metode penggorengan agar proses pengeringan lebih merata dan sempuna.

\section{DAFTAR PUSTAKA}

Andarwulan N., Feri K., dan Dian H., 2011. Analisis Pangan. Dian Rakyat. Jakarta.

AOAC.2005. Official Methods Of Analysis. Washington DC : AOAC.

Argo, B.D. Sugiharto.Y, Irianto, A.B., 2018. Analisis Kandungan Abon Ikan Patin (Pangasius pangasius) dengan Treatment Alat "Spinner Pulling Oil" sebagai Pengentas Minyak Otomatis Jurnal Keteknikan Pertanian Tropis dan Biosistem. Vol 6 No.1, Februari.

Ayustaningwarno,F. 2014. Teknologi Pangan, Teori Praktis dan Aplikasi.

Haryani,L. $\quad$ Widawati,L. $\quad$ Sari,E.R. 2014. Tepung Rebung Termodifikasi Sebagai Subtituen Terigu Pada Pembuatan Donat Kaya Serat, Agritepa, Vol I.No.1.

Hasan, K. 2010. Penetapan Kadar Protein Dengan Metode Spektrofotometri Dan Kadar Lemak Dengan Metode Sokletasi Pada Terung Korek Ungu Dan Terung Korek Hijau. Skripsi. Fakultas Sains Dan Teknologi. UIN Alauddin Makassar.

Montolalu S, N. Lontaan, S. Sakul, A. Dp. 
Mirah. 2013. Sifat Fisiko-Kimia dan Mutu Organoleptik Bakso Broiler dengan Menggunakan Tepung Ubi Jalar (Ipomoea batatas L). Jurnal ZootekVol. 32(5), Fakultas Peternakan Universitas Sam Ratulangi, Manado.

Nur'aini, H. Ishar. Darius. 2019. Inovasi Pengolahan Abon Lohan (Pilsbryoconcha exilis) Dengan Perlakuan Substitusi Tebu Telur (Saccharum edule), AGRITEPA, Vol. VI, No.1, Juli - Desember

Rauf, R. 2015. Kimia Pangan. C.V Andi Offset, Yogyakarta.

Rosiani, N., Basito, dan E. Widowati. 2015. "Kajian Karakteristik Sensoris Fisik Dan Kimia Kerupuk Fortifikasi Daging Lidah Buaya (Aloe vera) Dengan Metode Pemanggangan Menggunakan Microwave". Jurnal Teknologi Hasil Pertanian. Vol. 8. No. 2: 92-94.

Satiarini, B. 2006. Kajian Produksi dan Profitabilitas Pembuatan Susu Jagung. Skripsi.Departeman Teknologi Industri Pertanian. Fakultas Teknologi Pertanian. Institut Pertanian Bogor. Bogor.

Santoso, U., Setyaningsih, W., Ningrum, A., dan Ardhi, A. 2020. Analisis Pangan. UGM Press.

Tarwendah,I.P. 2017. Studi Komparasi Atribut Sensoris dan Kesadaran Merek Produk Pangan. Jurnal Pangan dan Agroindustri Vol.5 No.2:66-73 